Philosophy and Progress: Vols. LI-LII, January-June, July-December, 2012 ISSN 1607-2278 (Print), DOI :http://dx.doi.org/10.3329/pp.v51i1-2.17682

\section{MODERNITY IN PHILOSOPHY AND SOCIOLOGY: AN APPRAISAL WITH SPECIAL REFERENCE TO BANGLADESH}

\author{
Lipon Kumar Mondal*
}

\begin{abstract}
The paper aims to explore the philosophical and sociological foundations of modernity as well as to figure out the pattern of modernity in Bangladesh. Modernity in philosophy refers to the fundamental modification of pre-modern political philosophy of Socrates, Plato and Aristotle by Machiavelli, Copernicus, Kepler, Galileo, Bacon and Newton. Later, in this project, people who employed themselves as original contributors are Hobbes, Rousseau, Locke, Descartes, Spinoza, Leibniz, Kant, Hegel, Schopenhauer, Kierkegaard, Nietzsche, Russell, Heidegger, Popper, Foucault, Derrida, and so on. Amongst these thinkers some were associated to develop the project of modernity based on the Western epistemological and ontological contemplates and some were appeared as the critic of this mundane venture. Modernity, however,
\end{abstract}

\footnotetext{
${ }^{*}$ Lecturer, Department of Sociology, University of Dhaka Email: lipon@du.ac.bd
}

in sociology refers to the move from feudal social order to the capitalistic social order under the grand project of industrialization, secularization and rationalization. Modernity, from its commencement, possesses two innate characteristics: one is epistemological or conjectural which is the actual motif of philosophy, and another one is ontological or applied which is congruence to the motif of sociology. Both philosophy and sociology take modernity as a vocation and shared the same epistemological and ontological standpoints. In the context of Bangladesh I tried to explain modernity under the framework of philosophy and sociology as well as conceptualized the pattern of modernity as 'copied' because the type of modernity is found here as the simulation of Western and Eastern cultural and social values.

\section{Introduction}

The paper aims to explore the philosophical and sociological foundations of modernity as well as to figure out the pattern of modernity in Bangladesh with abstract and real life examples. Modernity in philosophy refers to the fundamental modification of pre-modern political philosophy-a modification having with the rejection of pre-modern political philosophy of Socrates, Plato and Aristotle (Strauss, 1958). Modernity, according to Russell, started in the early phase within the process of diminishing authority of the Church and the increasing authority of scientific values by some prominent scientists like Copernicus, Kepler, Galileo, and Newton (Russell, 1945:491-525). Modernity ${ }^{1}$, however, in sociology refers to the move from feudal/traditional social order to the capitalistic social order under the grand project of industrialization, secularization and rationalization (Habermas, 1990; Giddens, 1990; Beck, 1992; Barker, 2005).

The historical stages of modernity can be classified into seven stages: (1) the Renaissance $\left(14^{\text {th }}-16^{\text {th }}\right.$ centuries $),(2)$ the Reformation Movement $\left(16^{\text {th }}-17^{\text {th }}\right.$ centuries), (3) the Scientific 
Revolution $\left(16^{\text {th }}-17^{\text {th }}\right.$ centuries), (4) the Enlightenment $\left(18^{\text {th }}\right.$ Century), (5) the American War of Independence (1776), (6) the French Revolution (1789), and (7) the Industrial Revolution (late 18 th to early 19 th centuries) ${ }^{2}$. Along with these historical backgrounds modernity can also be categorized into three phases: firstly, early modernity-from 1453 to 1789 in traditional historiography and political philosophy by Machiavelli to Locke; secondly, classical modernity-from 1789 to 1914 by the writings from Descartes to Russell (Berman,1982); and finally, late modernity-from 1900 to 1989 by the contemporary authors such as Heidegger (1938), Popper (1944, 1945), Derrida (1981, 1996), Foucault (1966, 1969, 1975), Habermas (1990), Giddens (1990, 1991), Beck (1992), and Bauman (1989, 2000). Moreover, rapid social development brought by the science and reason have created some philosophical and sociological debates regarding the crisis of modernity. Thus, we find many scholars and schools engaged in this debate such as: Husserl's transcendental phenomenology, Scheler's phenomenology of values, Jaspers and Heidegger's existentialism, Gadamer's hermeneutics (Feng and Xing, 2006), critical theory of Marcuse and Habermas, and the postmodernism of Lyotard, Derrida, Baudrillard and Jameson.

The spokesmen of modernity, from Karl Marx to Daniel Bell, have argued that modernity welcomes such a vigorous economic development which brings pervasive super-structural changes i.e. social and cultural changes; but, others, from Max Weber to Samuel Huntington, have illustrated that cultural values have an enduring and autonomous control over economy, society and individual (Inglehart and Baker, 2000). On the contrary, some prominent thinkers argued that modernity as a grand project ended in the mid- or late-20th century and started the postmodern era which has been labeled as: the age of little narratives in which we find incredulous toward metanarratives - the narrative of humanity as the hero of liberty (Lyotard,1979); or, the age of the simulacrum-in which the real has been transformed into so many pseudoevents (Jameson, 1990 ); or, the age of simulation - in which signs and images found as hyper real (Baudrillard, 1981, 1994); or, the age of time-space compression - in which world has become a virtual grab bag and economy and social life has become hyper-globalized (Harvey, 1989).

Though the main attempt of this paper is to find out the features of modernity in philosophy and sociology in the context of Western society, I have endeavored to know the pattern of modernity in Bangladesh. As we know most of the Western scholars depict that the orient is not such a society where reason is the main instrument of social life. Accordingly, unlike Western modernity, I have conceptualized the pattern of modernity in Bangladesh as 'copied modernity'- a situation where we find the simulation of Western and Eastern pattern of modernity in the form of nebulous dilution. Modernity as a form of social order in India and latter in Bangladesh has been labeled as mixed or problematic or hybrid or ambivalent by the writings of Alex Inkeles (1969), Partha Chatterjee (1993), Homi Bhabha (1994), and Pranab Chatterjee (2010) respectively.

\section{Modernity in Philosophy}

As a form of unique scholarly transformation from metaphysical science to practical science, modernity in Western society started from the writings by the enlightenment thinkers who were pioneer in interpreting the modern world at the onset of reasoning and rationality. Ideas of modernity in 
philosophy can be traced back through the discussions on: (1) reason and rationality - by Descartes, Kant, Kierkegaard, Heidegger, Russell; (2) human dignity and freedom-by Montesquieu, Locke, Nietzsche; (3) society, state and lawby Machiavelli, Hobbes, Locke, Rousseau; (4) ontology and epistemology_by Descartes, Spinoza, Kant, Hegel, Schopenhauer, Sartre, Ryle; (5) ethics, morality and divinityby Descartes, Spinoza, Nietzsche, Russell; (6) secularism-by Machiavelli, Weber, Holyoake, Voltaire, Spinoza, Locke, Jefferson and Russell (7) skepticism ${ }^{3}$ — by Descartes, Spinoza, Berkeley and Hume; (8) science, technology and industrialism - by Copernicus, Kepler, Galileo, Bacon, Newton, Darwin, Marx, Durkheim, Heidegger; and (9) human sexuality - by Freud, Wollstonecraft and Beauvoir.

As a precursor political philosopher, Machiavelli vehemently demanded the separation of Church from the state which is considered as the preparatory point of modernity (Strauss, 1987). He was also concerned with factual and practical truth instead of idealism of traditional political philosophy and finally rejected the whole theological tradition (Strauss, 1958:86). In the 16th and 17th centuries, some great scientists had the sweeping influences on the whole human epistemology. For example, Copernicus presented new models of the solar system; Kepler used mathematics to fathom physics and the regularities of nature; and Galileo profoundly made his famous proof of uniform acceleration in freefall using mathematics (Kennington, 2004). Accordingly, we found Francis Bacon as a brain child of these three persons. As the founder of modern inductive method as well as logical systematization in science, Bacon proclaims that philosophy should be kept separate from theology because only inductive science can give us true knowledge which is consequently treated as the real source of power (Russell, 1945:541-44; Sorell, 1993:73).

Within this tradition, Hobbes as an empiricist devoted to mathematical reasoning for configuring the theory of social contract referring to the position against the state of nature where he sees life is solitary, poor, nasty, brutish and short; and, society is full of injustices, warfare, force and fraud (Russell, 1945; Berns, 1987). He also had a position against Plato and Aristotle in the question of reason and imagination respectively where he argued that reason is developed by industry; and imagination is a decaying sense, not a pure sense (Russell, 1945).

To find out the modern features of state, society and law in the query of freedom we should go through the discussions of Rousseau who argued that man was born free and everywhere he is in chains. Accordingly, man cannot find his freedom in any society; he can find his freedom only by returning from society - however good and legitimate- to nature (Strauss 1958:86). A second phase of modernist political thinking begins with Rousseau, who questioned the natural rationality of human and proposed that human nature was much more malleable than previously thought. As an upshot, this thought later influenced the political thinking of Immanuel Kant, Edmund Burke and others who made a critical review of modernist politics (Orin and Tarcov, 1997).

Locke, another influential thinker who is regarded as the founder of empiricism, advocates a doctrine of ideas where he sees that all of our knowledge, only with the possible exception of logic and mathematics, is derived from experience which can be found from two sources: first one is sensation, and second one is perception of the operation of our own mind or 
internal sense (Russell, 1945). He also discussed the social and political issues like the family, education, the church, constitutional government, and international relations where he argued that rights of the people must be protected by the state (Ward, 2010). In this convention, Locke, in his book Essay Concerning Human Understanding (1690) claimed that reason consists of two parts: first, an inquiry-what we know with certainty; second, an investigation-what we know with practice (Russell, 1945). Later, René Descartes, as one of the enlightenment thinkers and father of modern philosophy, denied the Scholastic-Aristotelian thesis by two fundamental ways: one is the rejection of substantial forms and their concomitant final causes in physics; and, another one is the refutation of the thesis that all knowledge must come from sensation (Descartes, 1637 and 1644). He is also one of the inventors of co-ordinate geometry; and, at first he used algebra to geometry. Influenced by the Galileo's new physics and theoretical deduction, Descartes argued that mathematics and geometry provided a model for producing scientific knowledge (Kennington, 2004); and, influenced by Beconian experimental observation and induction he also argued that it is possible to have practical understanding of regularities in nature (d'Alembert, 2009; Henry, 2004).

The Seventeenth century Dutch-Jewish philosopher Baruch Spinoza is regarded as the mastermind of the radical enlightenment and modern physical science (Jonathan Israel, 2001; Goldstein, 1983). He refused any transcendent god or ideal, and challenged the mind-body dualism what was predominant in Western thought (Spinoza, 1670). The intellectual legacy left by Spinoza's equation of God with nature undercut the religion-secularism divide defining postEnlightenment Europe which is said as the god-infused secularism - an imminent world in which the divine consists in all things, all individuated phenomena. This is also called the radical form of monotheism in Spinoza (Mack, 2010). Though, someone take it as a specifically secular-Jewish form of modernity (Goldstein, 1983).

In a sponging manner, it is argued that Leibniz's philosophy rests on Spinoza's ideas of radical enlightenment and Descartes' rationalism (Stewart, 2006). Leibniz is unsurpassed as a philosophical critic and mathematician of his age because of his modern logic and analytic philosophy (Israel, 2001). Basically, the modernity in his philosophy may be found in the Monadology and the Principles of Nature and of Grace where he tried to develop two logical premises: the law of contradiction and the law of sufficient reason-both depend upon the notion of an analytic proposition which, therefore, uses logic as a key to metaphysics (Russell, 1957). As a mathematician he made many contributions in studying the differential equations, method of separation of variables, reduction of homogeneous equations to separable ones, the procedure for solving first order linear equations and multinomial theorem (Bell, 1986; Broad and Lewy, 1975). Besides, in modern philosophy Immanuel Kant is the central figure who committed to synthesized early modern rationalism and empiricism emphasized on metaphysics, epistemology, ethics, political philosophy, and aesthetics. The elementary idea of Kant's critical philosophy, based on human autonomy, can be found in his three Critiques such as: the Critique of Pure Reason (1781, 1787), the Critique of Practical Reason (1788), and the Critique of the Power of Judgment (1790). By these writings, he argues that human understanding is the basis of the general laws of nature that structure all our experiences which never exist outside objects (Rohlf, 2010). Thus, scientific 
knowledge, morality, and religious belief are equally consistent and secure for the reason that they all rest on the same foundation of modern human autonomy.

As a modern thinker Hegel developed an ample philosophical framework under which we found the notion of Absolute Idealism that covers the wide-ranging issues of philosophy such as: the relation between mind and nature, the duality between subject and object of knowledge, the state, history, psychology, civil society, art, religion and so forth. Moreover, he argued that mind or spirit manifested itself in a set of contradictions and oppositions. His masterful dialectics of faith and reason is a spirited reminder where he argued that modern German thought begins with Martin Luther's act of emancipation, and Heinrich Heine's intellectual history (Hegel, 1807; Stewart, 2006). He is conceivably most well-known for his teleological account of history - an account which was later taken over by Marx and inverted into a materialist theory for the interpretations of historical advancements (Redding, 2010). At the core of Hegel's social and political thought we find freedom, reason, self-consciousness and recognition (Duquette, 2001). For Hegel, the essence of modernity is linked to the concrete social freedom and anti-capitalist idea (Hegel, 1811).

Later, Schopenhauer's basic philosophical contribution is epistemological idealism (Norman, 1958) which has been derived from his book The World as Will and Representation (1818) where he proclaimed that man can indeed do what he wants, but he cannot will what he wants. According to him, the Will is by nature a malignant and metaphysical existence which reins not only actions of individual and intelligent agents, but also organizes all observable phenomena. However, Schopenhauer, as a first Western scholar, also introduced the idea of Upanishad- treated as the production of the highest human wisdom, where he argued that the world is my will and representation and will has ontological primacy over the intellect. He is also the precursor to evolutionary theory and modern evolutionary psychology (Gray, 2002). In this line of thought, Søren Kierkegaard is also a renowned philosopher who surpasses the boundaries of philosophy, theology, literary criticism; and introduces the idea of existentialism. He has developed an incisive criticism of Hegel which gave him opportunity to work on the advancement of modernism, literary experimentation and representation of biblical figures (McDonald, 2012).

Besides, Friedrich Nietzsche as most notable critic of modernity challenged the foundations of Christianity ${ }^{4}$ and traditional morality by the framework of life-affirmation which includes profound discussions on individual autonomy, cultural health, life believing and creativity, power, and the realities of the world we live in (Wicks, 2011). Moreover, Nietzsche articulates some of the deepest core ideas of modernity in his book Beyond Good and Evil (1882), advocating the key values such as: individualism, growth, development, and the destruction of the old and the development of the new. His perspectives on modernity are highly aestheticist and culturalist. Thus his writings hold a trendy amalgamation of pre-modern, modern, anti-modern, and even postmodern impulses and positions; though it indicates the paradoxical element in his thought (Kellner, 1994).

Along with the tradition of G.E. Moore, Russell was deeply influenced by Leibniz and was generally credited as one of the founders of analytic philosophy ${ }^{5}$ who wrote on every major area of philosophy except aesthetics. He was particularly prolific in the field of metaphysics, logic, mathematics, 
philosophy of language, ethics, and epistemology. His most influential contributions related to the modern philosophy include: (1) defense of logicism - the view that mathematics is a sense of reducing logic; (2) refining of the predicate calculus - the way of building the formation of contemporary logic (3) defense of neutral monism - the view that the world consists of just one type of substance that is neither exclusively mental nor exclusively physical; and (4) theories of definite descriptions and logical atomism (Irvine, 2010). The core of his idea relating to modernity is found in logic which he sees as the study of valid reasoning.

As an original and key philosopher of the 20th century, Martin Heidegger is widely accredited. His main interest was ontology or the study of being; for example, in his fundamental treatise, Being and Time, he attempted to access being by means of phenomenological analysis of human existence in respect to its temporal and historical character (KorabKarpowicz, 2001). His ideas have exerted a seminal influence on the development of contemporary European philosophy. For example, his thinking has contributed to such diverse fields as phenomenology, existentialism, hermeneutics, political theory, psychology, and theology. His critique of traditional metaphysics and his opposition to positivism and technological world domination have been embraced by leading theorists of postmodernity like Derrida, Foucault, and Lyotard (KorabKarpowicz, 2001). Modernity is typically defined by him as a post-traditional and post-medieval historical period (Heidegger 1938, 66-67). For him, central to modernity is emancipation from religion, specifically from the hegemony of JudeoChristian belief (Fackenheim 1957, 272-73; Husserl, 1931).

After Heiddeger, we find Karl Popper who is regarded as one of the greatest philosophers of science (Thornton, 2013). In his writings we found three trends of modernity such as: (1) he was passionately devoted to the Marxist view of history, economics, and class-war which gave him a solid understanding of modern material world; (2) his reaction against fascism in Austria in the 1920s and 1930s developed an insight to write The Poverty of Historicism (1944) and The Open Society and Its Enemies (1945); and (3) he was profoundly influenced by the ideas of Freud and Adler as well as by the theory of relativity of Einstein which inspired him to make a theoretical framework regarding methodology which is labeled as falsification- a criterion for demarcating science from non-science (Thornton, 2013).

The features of modernity portrayed by Foucault and Derrida are mainly regarded as the critic of modernity or someone called it as the turn to postmodernity. Accordingly, Foucault developed a new perspective to make a critique ${ }^{6}$ of modernity and humanism along with the proclamation of the death of man. Foucault's critique of modernity is a particular episteme or power/knowledge regimes that govern historical periods and halt Weberian rationalism in order to perceive modernity in the tension between purposive rationality and autonomy (Fraser, 1985: 168,169). Moreover, he argued that modernity created a new form of domination through psychiatry, medicine, punishment, human sciences and various disciplinary apparatuses (Godfrey, 2012). In this convention, Jacques Derrida is accredited as an original contributor to postmodern philosophy because of his idea of deconstruction ${ }^{7}$ - a way of criticizing both literary and philosophical texts (Lawlor, 2002) as well as political, aesthetical and architectural theories. For Derrida, deconstruction has at least two aspects: literary-which concerns the textual interpretation in order to get hidden alternative meanings in the text; and philosophical 
-which concerns the application of deconstruction for invaliding metaphysics from Plato to Heidegger (Reynolds, 2002). In a nutshell, we find the features of modernity by the following Table 1:

\begin{tabular}{|l|l|}
\hline \multicolumn{1}{|c|}{ Table 1: } & \multicolumn{1}{|c|}{ Features of Modernity in Philosophy } \\
Thinkers & \multicolumn{1}{|c|}{ Features } \\
Miccolò & $\begin{array}{l}\text { Separation of Church from the state; factual } \\
\text { and practical truth instead of idealism of } \\
\text { traditional political philosophy; rejects the } \\
\text { whole philosophic and theological tradition. }\end{array}$ \\
\hline $\begin{array}{l}\text { Great scientists } \\
\text { in 16th and 17 }\end{array}$ & $\begin{array}{l}\text { Copernicus presented new models of the solar } \\
\text { system; Kepler used mathematics to fathom } \\
\text { physics and the regularities of nature; Galileo } \\
\text { profoundly made his famous proof of uniform } \\
\text { acceleration in freefall using mathematics. } \\
\text { These three thinkers are considered as the } \\
\text { pioneer of modernity in science as well as in } \\
\text { philosophy. }\end{array}$ \\
\hline Francis Bacon & $\begin{array}{l}\text { Founder of modern inductive method as well as } \\
\text { logical systematization in science; philosophy } \\
\text { should be kept separate from theology because } \\
\text { only inductive science can give us true } \\
\text { knowledge which is the real source of power. }\end{array}$ \\
\hline Jacque Rousseau & $\begin{array}{l}\text { Question raise regarding to freedom an empiricist Hobbes devoted to } \\
\text { powerful dimension of modernity): man was } \\
\text { born free and everywhere he is in chains; man } \\
\text { cannot find his freedom in any society; he can } \\
\text { find his freedom only by returning from } \\
\text { contract theory referring to the position against } \\
\text { society. thinkers on the state of nature. }\end{array}$ \\
\hline Thomas Hobbes
\end{tabular}

Table 1: Features of Modernity in Philosophy

\begin{tabular}{|c|c|}
\hline $\begin{array}{c}\text { Major } \\
\text { Thinkers }\end{array}$ & Features \\
\hline John Locke & $\begin{array}{l}\text { Founder of empiricism who claimed that our } \\
\text { knowledge is derived from experience which } \\
\text { has two sources-sensation and perception; for } \\
\text { him, reason consists of two parts: an inquiry- } \\
\text { what we know with certainty and an } \\
\text { investigation-what we know with practice; } \\
\text { reject religious dogmatism and portrait the } \\
\text { nature of state for human protection. }\end{array}$ \\
\hline René Descartes & $\begin{array}{l}\text { Father of modern philosophy who denied the } \\
\text { Scholastic-Aristotelian thesis by: the rejection } \\
\text { of substantial forms and their concomitant final } \\
\text { causes in physics and; the refutation of the } \\
\text { thesis that all knowledge must come from } \\
\text { sensation; one of the inventors of co-ordinate } \\
\text { geometry, and at first used algebra to geometry. }\end{array}$ \\
\hline Baruch Spinoza & $\begin{array}{l}\text { Mastermind of the radical enlightenment, } \\
\text { modernity and physical science; fuse } \\
\text { philosophical traditions with a Jewish } \\
\text { intellectual heritage in order to produce a } \\
\text { unique intellectual modern philosophy; refused } \\
\text { any transcendent god or ideal, and challenged } \\
\text { the mind-body dualism what is predominant in } \\
\text { Western modern thought }\end{array}$ \\
\hline G.W. Leibniz's & $\begin{array}{l}\text { Leibniz's philosophy addressed modern logic } \\
\text { and analytic philosophy; he offered two } \\
\text { logical premises in philosophy: the law of } \\
\text { contradiction and the law of sufficient reason- } \\
\text { both depend upon the notion of an analytic } \\
\text { proposition; mathematical contributions: } \\
\text { differential and linear equations. }\end{array}$ \\
\hline Immanuel Kant & $\begin{array}{l}\text { Synthesis of early modern rationalism and } \\
\text { empiricism into metaphysics, epistemology, } \\
\text { ethics, political philosophy, and aesthetics; } \\
\text { human autonomy is the basis of modernity and }\end{array}$ \\
\hline
\end{tabular}




\begin{tabular}{|c|c|}
\hline Table 1: & Features of Modernity in Philosophy \\
\hline \multirow[t]{2}{*}{$\begin{array}{c}\text { Major } \\
\text { Thinkers }\end{array}$} & Features \\
\hline & $\begin{array}{l}\text { the basis of general laws of nature that structure } \\
\text { all our experiences which never exist outside } \\
\text { objects. }\end{array}$ \\
\hline George Hegel & $\begin{array}{l}\text { Core of Hegel's philosophy: absolute idealism, } \\
\text { teleological account of history, reason, self- } \\
\text { consciousness and recognition; for Hegel, the } \\
\text { essence of modernity is linked to concrete } \\
\text { social freedom and anti-capitalist idea. }\end{array}$ \\
\hline $\begin{array}{l}\text { Arthur } \\
\text { Schopenhauer }\end{array}$ & $\begin{array}{l}\text { Modernity is embedded to his epistemological } \\
\text { idealism that tells: man can indeed do what he } \\
\text { wants, but he cannot will what he wants; he } \\
\text { made the ontological primacy over the intellect } \\
\text { enunciating that world is my will and } \\
\text { representation. }\end{array}$ \\
\hline $\begin{array}{l}\text { Søren } \\
\text { Kierkegaard }\end{array}$ & $\begin{array}{l}\text { Known as the father of existentialism; works } \\
\text { on: philosophy, theology, psychology, literary } \\
\text { criticism and fiction; projects on: advancement } \\
\text { of modernism, literary experimentation, } \\
\text { reinterpretation of biblical notions. }\end{array}$ \\
\hline $\begin{array}{l}\text { Friedrich } \\
\text { Nietzsche }\end{array}$ & $\begin{array}{l}\text { Essence of modernity- challenged the } \\
\text { foundations of Christianity and traditional } \\
\text { morality and declared that god is dead; core } \\
\text { ideas of modernity: individualism, growth, } \\
\text { development, innovation, and the destruction of } \\
\text { the old and the development of the new; he } \\
\text { synthesizes pre-modern, modern, anti-modern, } \\
\text { and even postmodern impulses. }\end{array}$ \\
\hline Bertrand Russell & $\begin{array}{l}\text { Founder of analytic philosophy; for him, study } \\
\text { of logic or valid reasoning is the essence of } \\
\text { modernity; works on anti-war and anti-nuclear } \\
\text { protests which he sees pivotal risk for } \\
\text { modernity. }\end{array}$ \\
\hline
\end{tabular}

\begin{tabular}{|c|c|}
\hline Table 1: & Features of Modernity in Philosophy \\
\hline $\begin{array}{c}\text { Major } \\
\text { Thinkers }\end{array}$ & Features \\
\hline Martin Heidegger & $\begin{array}{l}\text { The notion of modernity in his philosophy } \\
\text { embedded to: ontology, phenomenology, } \\
\text { existentialism, hermeneutics, political theory, } \\
\text { psychology and theology; he also gives the } \\
\text { attention to critique positivism and } \\
\text { technological rationality which is core to } \\
\text { modernity. }\end{array}$ \\
\hline Karl Popper & $\begin{array}{l}\text { His critique of modern philosophy includes: } \\
\text { society and politics, rationality, skepticism, } \\
\text { conventionalism, and relativism in science; } \\
\text { advocate and defender of the Open Society; } \\
\text { post modern aspects: falsifiability which nullify } \\
\text { all scientific theories. }\end{array}$ \\
\hline Michel Foucault & $\begin{array}{l}\text { The essence and critique of (post)modernity } \\
\text { can be found by his famous term 'discourse' } \\
\text { which works through power; for him, modern } \\
\text { society involves pervasive systems of control } \\
\text { and surveillance which cause the destruction of } \\
\text { human autonomy. }\end{array}$ \\
\hline Jacques Derrida & $\begin{array}{l}\text { The core of his (post)modern ideas embedded } \\
\text { to the notion of deconstruction by which he } \\
\text { claimed that whole Western philosophy is not } \\
\text { only Eurocentric and logo-centric but it is a } \\
\text { while mythology. }\end{array}$ \\
\hline
\end{tabular}

\section{Modernity in Sociology}

Modernity in sociology is considered as a social order that emerged in response to the schooling of Enlightenment and as a reaction to the social problems resulted from capitalism and industrialism (Harriss, 2000:325). Moreover, modernity, from Karl Marx to Daniel Bell, is seen as economic development that shapes the social and cultural world; and, from Max Weber 
to Samuel Huntington, it is seen as a cultural project which has an enduring and autonomous control over economy and society (Inglehart and Baker 2000). According to Anthony Giddens, modernity as a shorthand term for modern society, or industrial civilization which is associated with: (1) a certain set of attitudes towards the world or openness to transformation, (2) a complex of economic institutions, and (3) a certain range of political institutions, including the nation-state and mass democracy (Giddens, 1998:94). The era of modernity ${ }^{8}$ is characterized socially by industrialization and the division of labor (Durkheim, 1893) and philosophically by the loss of certainty (Delanty, 2007). Various 19th century intellectuals, from Auguste Comte to Karl Marx to Sigmund Freud, attempted to offer scientific ideologies in the wake of secularization and therefore modernity is described as the age of ideology (Delanty, 2007).

Among the great modernists in sociology at the classical phase we found Comte, Spencer, Marx, Durkheim, Weber, Toennies and Freud. But in the ambivalent phase, we find Luckas, Gramsci and Marcuse; and, in contemporary time we found Parsons, Inkeles, Lerner, Eisenstadt, Habermas, Beck, Bauman and Giddens. Let me begin with the discussion from the classical phase of modernity. Auguste Comte, the father of sociology, invented the term positivism ${ }^{9}$ as a method of studying society scientifically where he seeks to get the objective knowledge by which, he believes, a moral consensusbased society is possible. Comte classified the whole history of human epistemology into three stages such as: (1) theological - the age when man's place in society and society's restrictions upon man were referenced to God, (2) metaphysical - the extension of theological stage where people often tried to believe that God is an abstract being or force that guides and determines the events in the world, and (3) positivistic - known as the scientific stage that refers to scientific explanation based on observation, experiment, and comparison (Allan, 2013). For Comte, modernity started with the phase of positivism while capitalism worked as the main force of social order. Another earlier functionalist Spencer claimed that modernity starts at the period of super organic conditions of society - a capitalist or industrial social force which has appeared after passing the period of inorganic and organic societal conditions.

Later, Karl Marx as the most brilliant vindicator and criticizer ${ }^{10}$ of modernity, gives a comprehensive social view of the birth and development of capitalist modernity that began with the Second Industrial Revolution and still exists today (Antonio, 2003). He explored various aspects of modernity that was inherent in the logic of capital, resided in the process of historical evolution, arose in social conflicts and segmentations, and presented itself in a global horizon (Feng and Xing, 2006: 254). In Marx's philosophy, Feng and Xing also found two contrasting opinions: firstly, it is regarded as a genre of modernist philosophy alongside evolutionism, essentialism, rationalism and centralism what are best known as grand narrative, and secondly, it is regarded as a genre of postmodernist philosophy to the extent that postmodernity is considered to be the essence of Marx's philosophical revolution and the rejection of metaphysics. The specific meaning of Marx's modernity is the capitalist society that is based on industrialization and is seen as:

All fixed, fast-frozen relations, with their train of ancient and venerable prejudices and opinions, are swept away, all new formed ones become antiquated before they can ossify. All that is solid melts into air, all that is holy is profaned, and men at last are forced to face ... the real 
conditions of their lives and their relations with their fellow men (Marx and Engels, 1848).

Moreover, we found the basic elements of modernity in Marx's notion of the primitive capital accumulation, class and class struggle, alienation, labor theory of value, surplus production, commodification of labor, commodity fetishism and so forth (Marx, 1848, 1853, 1857, 1867, 1894). In addition, we found in Marx the following pattern of transformation ${ }^{11}$ in people's relationships in the era of bourgeoisie capitalism such as:

The bourgeoisie has torn apart the many feudal ties that bound men to their "natural superiors," and left no other bond between man and man than naked interest, than callous cash payment. It has drowned the heavenly ecstasies of pious fanaticism, of chivalrous enthusiasm, of philistine sentimentalism, in the icy water of egoistical calculation ... The bourgeoisie has stripped of its halo every occupation hitherto honored and looked up to with reverent awe ... The bourgeoisie has torn away from the family its sentimental veil, and turned the family relation into a pure money relation ... In place of exploitation veiled by religious and political illusions, it has put open, shameless, direct, naked exploitation ( Marx and Engels, 1848). ${ }^{12}$

After Marx, Durkheim embarks upon modernity from a different angle by taking the ideas from Saint-Simon as regards to industrial social order. In the analysis of modernity by Durkheim we find that he draws less attention to the rising of the bourgeoisie as a new revolutionary class or the advent of capitalism as the new mode of production, but his fundamental urge to modernity is rather linked to the question of industrialism - a way of life or social order based on the new science and technology (Larraín, 2000:13). Articulating a contrasting view of modernity in the Division of Labor,
Durkheim drew a counter-Enlightenment position by which he claimed that the collective conscience ${ }^{13}$ remained an integral part of modern society (Durkheim, 1947; Seidman, 1985:10912). In this context, his principal aims was to demonstrate the substantial changes brought by the collective conscience- in the form of social differentiation and individuation- in society which has been transformed from traditional to modern social types (Lukes, 1973; Poggi, 1972). The features of modernity also have been extended and modified in Durkheim's subsequent writings, for example:

$\ldots$ in "Individualism and the Intellectuals" Durkheim reverses his position by claiming that the religion of humanity is destined to be the only basis of societal-wide moral community... in "Suicide" Durkheim links problems of moral community with problems of personal identity and meaningful existence... in "The Elementary Forms of Religious Life" Durkheim asserts the permanence and pervasiveness of the sacred in society, yet reveals an ambivalence about meaning and moral life in modernity (Seidman, 1985:115)

As one of the founding figure of modernity Weber is widely recognized because of his two most notable contributions: rationalization thesis - a grand meta-historical analysis of the dominance of the west, and the Protestant Ethic thesis - a non-Marxist genealogy of modern capitalism (Kim, 2012). In other words, modernity is closely associated, in his writings, with the processes of rationalization and disenchantment of the world (Larraín, 2000:13). Accordingly, Weber exclaimed that the Protestant ethic initiated the Western reason and rationality which ultimately made the people's life disenchanmented - a dissolution realm of mystic life (Feng and Xing, 2006:259). Moreover, Weber protracted the perception of modernity through the two intrinsic ideas such as: 
undercutting the possibility of individual creativity and autonomy by the bureaucratic suppression ${ }^{14}$; and the end of cognitive confinement with the rise of secularism, positivism, and historicism (Seidman, 1985:110). According to Weber, the inexorable order, for example capitalistic, legalistic and bureaucratic, determines ${ }^{15}$ the lives of people in modern world which is irresistible force (Weber, 1904-5). Furthermore, a dialectical perspective of modernity may be found in some of Weber's later essays, for instance Politics as a Vocation and Science as a Vocation.

The question of modernity in Ferdinand de Toennies, who is influenced by Thomas Hobbes (Wirth,1926), can be traced out through the analysis of two social groupings- Gemeinschaft (or community) and Gesellschaft (or society) which are associated with the basic uniqueness whereas Gemeinschaft incorporates the values of emotion, irrationality, attachment, trust, rural views; but, per contra, Gesellschaft refers to the values of calculability, rationality, artificiality, profit, individualistic, instrumental and exploitative (Toennies, 1912) . These two social groupings are basically based on two basic forms of will: organic will or "Wesenwille" - an actor who will see himself as a means to serve the goals of social grouping as an underlying, subconscious force which is associated with the Gemeinschaft; and the other will is the reflective will or "Kürwille" - an actor who sees a social grouping as a means to serve the goals of individual as a purposive and future-oriented force which is link to the Gesellschaft (Freund, 1978).

Sigmund Freud, the founder of psychoanalysis, tried to make the modern interpretation of human neurotic condition connecting to the repressed sexual thoughts and fantasies of early childhood. Freud was arguably the first thinker to apply the Eros (life instinct)—which covers all the self-preserving and erotic instincts and Thanatos (death instinct)-which covers all the instincts towards aggression, self-destruction, and cruelty for interpreting the development of human personality system and unconscious level (Thornton, 2010). Besides, he claims that modern capitalist system is responsible for generating the repressive sublimation which is a key feature of modernity. By the following table 2 (see table 2) we can summarize the features of pre-modernity and modernity drawn by the classical sociologists and psychologists.

\begin{tabular}{|l|l|l|}
\hline \multirow{2}{*}{ Theorists } & \multicolumn{2}{|c|}{$\begin{array}{c}\text { Table 2: } \\
\text { Modernity in Classical Sociology }\end{array}$} \\
\cline { 2 - 3 } & \multicolumn{1}{|c|}{$\begin{array}{c}\text { Traditional } \\
\text { Society }\end{array}$} & \multicolumn{1}{c|}{ Modern Society } \\
\hline $\begin{array}{l}\text { Aguste } \\
\text { Comte }\end{array}$ & $\begin{array}{l}\text { Theological and } \\
\text { metaphysical } \\
\text { condition of } \\
\text { society }\end{array}$ & $\begin{array}{l}\text { Positivistic social order is the } \\
\text { starting point of modernity; } \\
\text { positivism is the essence of } \\
\text { modernity. }\end{array}$ \\
\hline $\begin{array}{l}\text { Karl } \\
\text { Marx }\end{array}$ & $\begin{array}{l}\text { Ancient, slavery } \\
\text { and Feudal } \\
\text { society }\end{array}$ & $\begin{array}{l}\text { Social order of modernity is } \\
\text { capitalistic; matters transformed } \\
\text { into commodity; } \\
\text { commodification of labor; } \\
\text { alienation; all that is solid melts } \\
\text { into air. }\end{array}$ \\
\hline $\begin{array}{l}\text { Herbert } \\
\text { Spencer }\end{array}$ & $\begin{array}{l}\text { Military society } \\
\text { Modernity is link to the } \\
\text { industrial society; the key to } \\
\text { modernity of Spencer is social } \\
\text { Darwinism-the philosophy of } \\
\text { the survival of the fittest. }\end{array}$ \\
\hline $\begin{array}{l}\text { Emile } \\
\text { Durkheim }\end{array}$ & $\begin{array}{l}\text { Mechanical } \\
\text { solidarity based } \\
\text { society (strong } \\
\text { solidarity exist) }\end{array}$ & $\begin{array}{l}\text { Modernity is linked to the } \\
\text { question of industrialism -a } \\
\text { way of social order based on the } \\
\text { new science and technology; } \\
\text { anomie is the main discontents } \\
\text { of modernity; organic solidarity } \\
\text { based society is the formation of } \\
\text { the modernity. }\end{array}$ \\
\hline
\end{tabular}




\begin{tabular}{|l|l|l|}
\hline \multirow{2}{*}{ Theorists } & \multicolumn{1}{|c|}{$\begin{array}{c}\text { Table 2: } \\
\text { Modernity in Classical Sociology }\end{array}$} \\
\cline { 2 - 3 } & \multicolumn{1}{|c|}{$\begin{array}{c}\text { Traditional } \\
\text { Society }\end{array}$} & \multicolumn{1}{c|}{ Modern Society } \\
\hline Max & $\begin{array}{l}\text { Traditional or } \\
\text { irrigational } \\
\text { society, } \\
\text { enchanted } \\
\text { religious views }\end{array}$ & $\begin{array}{l}\text { Disenchanmented-a dissolution } \\
\text { realm of mystic life; } \\
\text { rationalization brings the } \\
\text { formation of capitalism and } \\
\text { bureaucracy; market based class } \\
\text { formation; asceticism and capital } \\
\text { accumulation. }\end{array}$ \\
\hline $\begin{array}{l}\text { Ferdinand } \\
\text { Tonnies }\end{array}$ & $\begin{array}{l}\text { Gemeinshaft } \\
\text { (rural society): } \\
\text { conflict, } \\
\text { cooperation, } \\
\text { fusion, } \\
\text { integration, } \\
\text { solidarity, } \\
\text { communication; } \\
\text { society based on } \\
\text { organic will or } \\
\text { irrationality. }\end{array}$ & $\begin{array}{l}\text { Gesellschaft (modern society) } \\
\text { includes the features: } \\
\text { accommodation, association, } \\
\text { hostility, tension, dissolution, } \\
\text { rivalry and revolt; basic form of } \\
\text { modernity is reflective will that } \\
\text { possesses: rationality, calculation, } \\
\text { artificiality, ambiguity. }\end{array}$ \\
\hline $\begin{array}{l}\text { Sigmund } \\
\text { Freud }\end{array}$ & $\begin{array}{l}\text { and Ego based } \\
\text { society; } \\
\text { decentralization } \\
\text { of Eros and } \\
\text { sexuality. }\end{array}$ & $\begin{array}{l}\text { Civilization starts imposing taboo } \\
\text { on sexual promiscuity; the founder } \\
\text { of psychoanalysis and unconscious } \\
\text { mind; repressive sublimation is the } \\
\text { vanguard of modern civilization. }\end{array}$ \\
\hline
\end{tabular}

Now the ambivalent phase of modernity in the Western society can be found by the writings of Neo-Marxian theorists namely Lukács, Gramsci and Marcuse. In this tradition, Lukács is the forerunner of modernity interpreter in the context of neoMarxism and Weberian rationalism. As J. H. Turner claimed:

Lukács blended Marx and Weber together by seeing a convergence of Marxist ideas about commodification of social relations through money and markets with Webwer's thesis about the penetration of rationality into evermore sphere of modern life (Turner, 2003:202).

Borrowing the Marxian term of commodity fetishism, Lukács employed the concept of reification to denote the process by which social relationships becomes objects that can be manipulated, bought and sold. He also revised the class consciousness of Marx adding the dimension of imputed class consciousness which is capable to raise the proletarian epistemology for social change through class struggle. After Lukács, we find Gramsci who also blend Hegel, Marx and Weber in his works. He concluded the turning of Marx's ideas back into more Hegelian mode which is viewed cultural forces as the determining factors of material relations in society rather than view ideas as reflections of the material structure of society (Turner, 2003:204-5). Moreover, Gramsci is influenced by the idea of Weber for explaining the term hegemony by which he meant a spontaneous consent of subordinate groups to the dominated ones (Gramsci, 1971).

Later Marcuse's One-Dimensional Man became the dominant paradigm in critical thought who proclaimed that both Marx and Freud are obsolete because the idea of class and social struggles by Marx and the notion of psychological conflicts and contradictions by Freud have been abolished by the state of total administration (Berman, 1982:28). In this context he argued:

The masses have no egos, no ids, their souls are devoid of inner tension or dynamism; their ideas, their needs, even their dreams, are "not their own"; their inner lives are "totally adminitered," programmed to produce exactly those desires that the social system can satisfy and no more (Berman, 1982:29)" ... "The people recognize themselves in their commodities, they find their soul in their 
automobiles, hi-fi sets, split-level homes, kitchen equipments (Marcuse, 1964:9).

As a contemporary thinker, Talcott Parsons was a defender of modernity and saw modern technology and modern forms of organization as essentially liberating and progressive instead of traditional ones (Mayhew, 1984). Parsons draws a schema by a set of five dichotomies for differentiating modern society from traditional one. The dichotomies are (also known as pattern variables): ascription/achievement, particularism/universalism, diffuseness/specificity, collectivity/self and affectivity/affective neutrality (Parsons, 1951; 1968). He also dealt with the problem of modernity appeared in family and marriage system as well as in social and cultural system by his functionalist perspective.

Like other $20^{\text {th }}$ century major philosophers namely Wittgenstein, Heidegger, Popper and Derrida, Habermas devoted to overcome traditional metaphysical philosophy as philosophy of consciousness by introducing the paradigm of mutual understanding what he calls as communicative theory of action (Habermas, 1990a:296-98). Accordingly, at the heart of Habermas's theory of communicative action - derived from Immanuel Kant and Karl Popper - we find three types of world views where he distinguishes the objective world, the social world and the subjective world. For example: (1) truth-which refers that the objective world is valid because it corresponds to the reality; (2) truthfulness - that refers to the subjective world because it claims about the abstraction of the reality; and (3) rightness - a claim that refers to the social world because it does not contradict commonly agreed social norms (Habermas, 1984, p. 440). Finally, Habermas claimed that the crisis in modernity can be removed by the reconstruction of modernity ${ }^{16}$ on the basis of "communicational reason" (Feng and Xing, 2006:265).
Later, Zygmunt Bauman, a critical thinker, defined modern age as the kingdom of reason and rationality which have the following motto: reason against emotions or animal instincts, science against religion and magic, truth against prejudice, correct knowledge against superstition, reflection against uncritical existence, rationality against affectivity and the rule of custom (Bauman, 1989; Vries et al., 2005). For Bauman, modernity is a 'movement with a direction'-a direction driven by universalization, systemization and rationalization (Bauman, 1991). He argued that modernity starts when space and time are separated from living practice and from each other (Bauman, 2000:8). Besides, Bauman labeled late modern consumer society as liquid modernity which is different from the modernity of his Holocaust. He proposed liquid modernity, in consumer society, as a more apt term for making sense of changes and continuities in modernity (Lee, 2005:61). Another late modernist, Ulrich Beck argued that modernity broke down agricultural society in favor of industrial society but, per contra, second modernity transforms industrial society into a new and more reflexive network or information or risk society (Beck, 1992; He, 2012:111-215). Risk society, according to Beck, is a form of reflexive modernity which is marked by a new awareness of the risksrisks to all forms of life, plant, animal and human - created by the very successes of modernity (Ritzer and Goodman, 2003; Nordmann, 2010). Moreover, his second modernity has close attachment to the changing pattern of intimate relationships which he identifies as the normal chaos of love (BeckGernsheim and Beck, 1995; Harding, 2008).

Anthony Giddens, a towering figure of late modernity, defines modernity in terms of four basic institutions such as: (1) capitalism - it is characterized by commodity production, private ownership of capital, wage labor, and a class system 
derived from these characteristics; (2) industrialism - that involves the use of inanimate power sources and machinery to produce goods, but it also affects transportation, communication, and everyday life; (4) surveillance-which refers to the supervision of the activities of subject populations in the political sphere; and (4) control of the means of violence by the state (Giddens, 1990; Ritzer and Goodman, 2003). Moreover, according to Giddens (1991:1) modernity must be understood on an institutional level. In this context he discusses three features of modern institutions such as: (1) time and space distanciation - that refers to the tendency for modern relationships to be increasingly distant'; (2) disembedding mechanisms - which involves the lifting out of social relations from local contexts of interaction and their restructuring across indefinite spans of time-space; and (3) reflexive appropriation of knowledge or reflexivity-- that means that the social practices of modern society are constantly reexamined and reformed in the light of incoming information (Giddens, 1990:53; Ritzer and Goodman, 2003).

According to Lyotard, modernity is necessarily connected with capitalism (Feng and Xing, 2006:256). For Lyotard, modernity is based on three institutional dimensions of rationalization such as: (a) economic rationalizationsubjection of and total control over nature; (b) political rationalization - subjection of and total control over politics and (c) scientific rationalization - the possibility of gaining objective knowledge (Mourad, 1997; Vries et al., 2005). But to perceive Harvey's ideas of modernity one must have a notion about time-space compression that he discussed in The Condition of Postmodernity, 1989. According to Harvey, the word 'compression' means that the world becomes smaller and smaller and the time in the world also declines because of technological advancement, flexible capital accumulation, and international flows of capital. For example, Harvey mentioned that through these developments the world has become seventy times smaller between 1500 and 1960, in the question of time for travelling (Vries et al., 2005). In the same tradition, Manuel Castelles examines the emergence of a new society, culture, and economy in the light of the revolution in information technology. For him, societies are being structured with a bipolar opposition between the Net and the self which instigates to reconstruct the historically determined relationships of production, experience and power; where, production is organized in new type of class relationships, consumptions and investments; experience is structured around gender/sexuality and loosely-structured patriarchalism; and power is founded upon the state and its institutionalized monopoly of violence (Castells, 2000:3-15).

\section{Modernity in Bangladesh}

Modernity, according to Timothy Mitchel (2010), started to be staged in the Western and later in the non-Western societies as a form of singular, original, present, and authoritative. Modernity as a form of social order in India as well as in Bangladesh, from medieval period to the present, has been labeled as ambivalent in the book The Story of Ambivalent Modernity in West Bengal and Bangladesh: The Rise and Fall of Elitism, 2010 by a renowned sociologist Pranab Chatterjee. According to Chatterjee, Bangladesh as a Third World country, and, of course, the part of pre-British India (1204 to 1757), entered into modernity by the process of Sanskritization and Islamization where modernity was based on the caste and religious divisions respectively. Later, in the phase of British India (1757-1947), he also argued that Bangladesh as a constituency started its journey toward modernity based on the conflict in knowledge, identity and loyalty. After the partition of India, Bangladesh became the part of newly born state of 
Pakistan where modernity can be traced back based on conflict between Islamization, Bengali nationalism, Marxism and peasant democracy (Chatterjee, 2010).

In answering the question of how modern we are, Alex Inkeles with his colleagues (1969) examined the impact of modernization process on six developing countries including Bangladesh. This study was conducted by the 300 entries including attitudes, values, verbal ability, literacy, politics, intelligence, and psychic adjustments. The findings of this study showed that modernity is in its inception phase, though some urban sects are modern in terms of their life style and social conditions. Partha Chatterjee, a renowned thinker on South Asia, in his book The Nation and Its Fragments: Colonial and Postcolonial Histories, 1993 raised the question how modernity ought to be understood in the postcolonial context. In answering the question he makes the argument by offering two types of modernity such as thematic modernityWestern style modernity and problematic modernitycolonized form of modernity or the victim of modernity. Chatterjee also argues that the problematic modernity in Indian context reveals neither modern rationality nor individual freedom; and it cannot be claimed as universal or immutable in absolute sense. For him, modernity manifests itself in its "other" non-Western world through the avatars of colonial oppression and aggressive separatist movements.

Another renowned post-colonial theorist Homi Bhabha reevaluates modernity in the conception of cultural hybridity in his book The Location of Culture, 1994 where he argues that cultural hybridity is consequential results which has been derived from various forms of colonial cultural collisions and interchanges. Drawing examples from South Asia he developed psychoanalytic approaches of modernity having with the tradition of Frantz Fanon. Moreover, his framework of post- colonial modernity is based on the underlying ideas of the British missionaries and colonial administrators. Besides, Arjun Appadurai, a renowned Indian anthropologist, portraits an influential theoretical analysis of modernity in his book Modernity at Large: Cultural Dimensions of Globalization, 1996 where he argued that the idea of nation state- the core of the modernity- has already become obsolete because of transition from international to post-national political order-a situation where we find "diasporic public spheres" or ethnic pluralism.

But the Western scholars depict that the orient is not such a society where reason is the main instrument of social life. Accordingly, unlike Western modernity, we find the pattern of modernity in Bangladesh as 'copied modernity'- a situation where we find the simulation of Western and Eastern pattern of modernity in the form of nebulous dilution of cultural and social values. In philosophical point of view, it can be argued that modernity in Bangladesh is not based on the reform movement or industrial revolution or on Western like enlightenment and renaissance; rather it is imposed and imitated. Moreover, we do not find any rational and widely accepted materialist school of thought in our social life parallel to the West. This is why we find mystified social world in our major traditional views like Hinduism, Islam, Buddhism, Charvaka (it was rarely practiced), and Jainism.

Sociologically speaking, the pattern of social order in India and Bangladesh has been labeled as mixed or problematic or hybrid or ambivalent by the writings of Alex Inkeles (1969), Partha Chatterjee (1993), Homi Bhabha (1994), and Pranab Chatterjee (2010) respectively. In reality, modernity, for Giddens (1990), must be understood on an institutional level. If we justify this statement in the context of our society we find only the informal practices in our political, economic and 
social institutions. For example: political institutions have the following practices such as: unyielding factionalism and prejudiced political culture, passive democratic system, pluralistic ignorance, fascist behavior and many others things. Moreover, for bureaucracy and judiciary system we find massive corruption, law for repression, coercion, justice for the powerful people, absence of accountability and transparency etc. For economic institutions we find unduly cash nexus and vulgar plundering through stock market crash, vandalism, violence, plundering, trafficking, smuggling, kinship ties, bribe, donation, land grabbing, monetary scam, killing, threatening, occupational power, global connectivity, liaise with international agency etc. In social institutions we find numerous anomalies and irregularities like widely practiced nepotism and regionalism, absence of secularism, mysticism, religious fundamentalism, politicized education, immoral behavior etc. Thus, it can be said that our institutional practices, on which the pattern of modernity is dependent, are the asymmetrical fusion of western and local derivates which is sensible to conceptualize as copied modernity. Because the urban people are here imitating the Western so-called good or bad values and cultures and the rural people are following their urban people. So, it is all about the process of simulation between the Western and Eastern or urban and local values and cultures which is shaping and reshaping our modernity as a whole.

\section{Conclusion}

Modernity from its inception possesses two intrinsic characteristics: one is epistemological or conjectural which is the motif of philosophy, and another one is ontological or applied which is analogous to sociology. Both philosophy and sociology, I think, take modernity as a vocation and shared the same epistemological and ontological standpoints. For example, modernity is characterized by the emphasis given on reason and experience which bring such a social order that accelerates the process of rising modern science and technology. This scientific rationality promotes such a modernity which refers to radical societal changes which include: the advent of rational capitalism, the rise of industrialism as a way of life, the practices of religious pluralism and secularism, the rise of the self and so forth. Moreover, modernity presents us a reflexive, autonomous, and rational idea which eventually gained a control over the nature and declared the death of God; and this is the way we find the essence of modernity.

In searching the response to the critique of modernity as well as its discontents, we find Nietzsche, Marx, Weber, Freud, Heidegger, Habermas who stand in a same line and speak on rationality, alienation, bureaucracy, repression, instrumental rationality and communicative reason respectively. In this milieu, Marx summarized the radical historical contingency as "all that is solid melts into air" and by a pessimistic mode Weber argued that in modern society the rationalization of life traps individuals in an 'iron-cage' of rule. Moreover, Heidegger argued that modernity is a unique way of making exploitation through instrumental rationality. Likewise, Habermas criticized the modern notion of subject-centered reason by developing theories of communicative rationality and Foucault also claimed that modern society involves pervasive systems of control and surveillance which causes the destruction of human autonomy. In the context of Bangladesh, modernity is not based on industrial order; rather, it is based on the simulation of Western and local social and cultural order. In other words, it is copied in nature because we are changing ourselves and our social world through the Western modernization and Eastern sanskritization process. 


\section{References}

1. In this context, Tate (1997) sees it from both sides where he mentioned that modernity had its philosophical roots in the Enlightenment, and its sociological roots in the broad social, economic and political changes connected to the vigorous upheavals of the industrial and French revolutions. Thus these two dimensions of modernity intertwined (Tate, 1997).

2. These categories have been adapted from the ideas of Eric Hobsbawm's trilogy as: The Age of Revolution: Europe 17891848; The Age Capital: 1848-1875; and The Age of Empire (1875-1914)

3. Western ancient skepticism (e.g. Sextus Empiricus) in philosophy is also resemblance to the ancient Eastern skepticism (e.g. Buddhism, Charvaka, and Jainism).

4. According to Nietzsche, Christianity is the most fatal and seductive lie that ever existed (Russell, 1945:765).

5. His philosophy is analytic because he sees that truths are known by logic and experience or in other words, truth lies between the two extremes of ideas and practical life (Russell, 1945:590).

6. Habermas (1981) argued that Foucault denied the emancipatory potential of modernity (Koopman, 2010:551).

7. Though, Habermas considered the idea of deconstruction as irrational and anti-modern (Huttunen, 2007).

8. The modern age is marked by the separation of church and state. Prior to modernity, the primary form of government was feudalism, which was based on land tenure and personal relationships (Allan, 2013:4).

9. According to Comte, there are three foundations of positivism: (1) the idea of human mind and knowledge which progressed through three distinct phases: theological, metaphysical, and positivistic, (2) everything within this universe is empirical and operates by natural laws and (3) science as the best way to improve human existence (Allan, 2013:6).
10. Marx's critique of the modernity of capitalism concentrated in two periods: the earlier one was the critique of the ideological period, the later one was the critique of a politico-economic period (Feng and Xing, 2006:260).

11. Where, in Marx's syntax, "the bourgeoisie" is the subject in its economic activities that bring the big changes in modern men and women of every class (Berman, 1982:105-6).

12. I have taken this comment of Marx and Engels from Berman (1982:106).

13. The collective conscience refers to those beliefs, symbols, and sentiments that shared by all members of a society.

14. This is seen, according to Weber, as "an iron cage."

15. In another word, it is bound to determine man's fate until the last ton of fossilized coal is burnt out (Berman: 1982:27).

16. In this context, Shmuel Eisenstadt, another influential modernist, introduced the concept of "multiple modernities" joining the contemporary debate on economic globalization, the comparative analysis of civilizations, and the post-colonial perspective of "alternative modernities" (Delanty, 2007).

\section{Works Cited}

Allan, Kenneth. 2013. Explorations in Classical Sociological Theory: Seeing the Social World. Sage Publications Inc.

Antonio, Robert J. 2002. Marx and Modernity: Key Readings and Commentary. Blackwell Publishers.

Barker, Chris. 2005. Cultural Studies: Theory and Practice. London: Sage.

Barnett, T. 1988. Sociology and Development. London: Hutchinson. Bauman, Zygmunt. 2000. Liquid Modernity, Cambridge: Polity.

Beck, Ulrich. 1992. Risk Society: Towards a New Modernity. London: Sage. 
Berman, Marshall. 1982. All That Is Solid Melts into Air: The Experience of Modernity. New York: Simon and Schuster.

Berns, Laurence. 1987. “Thomas Hobbes". In History of Political Philosophy, third edition, edited by Leo Strauss and Joseph Cropsey, 369-420. Chicago: University of Chicago Press.

Chaterjee, Pronab. 2010. A Story of Ambivalent Modernization in Bangladesh and West Bengal: The Rise and Fall of Bengali Elitism in South Asia. Peter Lang.

d'Alembert, Jean Le Rond. 2009. "Preliminary Discourse",The Encyclopedia of Diderot \& d'Alembert Collaborative Translation Project, translated by Richard N. Schwab and Walter.

Delanty, Gerard. 2007. "Modernity." Blackwell Encyclopedia of Sociology, edited by George Ritzer. 11 vols. Malden, Mass.: Blackwell Publishing.

Derrida, J. 1981. Positions. Chicago: The Chicago University Press.

Dukheim. Emile. 1947. The Division of Labor in Society.New York: The Free press (originally published in 18930).

Eisenstadt, Shmuel Noah. 2003. Comparative Civilizations and Multiple Modernities, 2 vols. Leiden and Boston: Brill.

Feng, Ziyi and Xing, Lijun. 2006. "A Contemporary Interpretation of Marx's Thoughts on Modernity," Frontiers of Philosophy in China, 1(2):254-268.

Freund, Julien. 1978. "German Sociology in the Time of Max Weber" in T. B Bottomore and R Nisbet's A History of Sociological Analysis; 1978:152-57

Giddens, Anthony. 1991. Modernity and Self-Identity: Self and Society in the Late Modern Age. Cambridge: Polity.

Godfrey, Luke. 2012. "Foucault's Interpretation of Modernity," October 26, 2012; e-international relations.

Habermas, Ju"rgen. 1990. The Philosophical Discourse of Modernity: Twelve Lectures. MIT Press.
Harvey, David. 1989. The Condition of Postmodernity: An Enquiry into the Origins of Cultural Change, Blackwell Publisher.

Inglehart, Ronald and Baker, Wayne E. 2000. "Modernization, Cultural Change, and the Persistence of Traditional Values"American Sociological Review, Vol. 65 (February: 1951).

Inkeles, Alex. 1969. "Making Men Modern: On the Causes and Consequences of Individual Change in Six Developing Countries." in From Modernization to Globalization: Perspectives on Development and Social Change, (Ed) J Timmons Roberts and Amy Hite.

Irvine, A. D. 2010. "Bertrand Russell," Stanford Encyclopedia of Philosophy First published, Dec 7, 1995.

Israel, Jonathan I. 2001. Radical Enlightenment: Philosophy and the Making of Modernity. New York, Oxford University Press.

Jameson, F. 1990. Postmodernism, or, the Cultural Logic of Late Capitalism. Durham: Duke University Press.

Kant, Immanuel. 1781. Critique of Pure Reason, tr. by Werner S. Pluhar and Patricia Kitcher (Hackett, 1996)

Kellner, Douglas. 1994. Modernity and Its Discontents: Nietzsche's Critique, retrieved from: (http://www.gseis.ucla.edu/faculty/ kellner/).

Kim, Sung Ho. 2012. "Max Weber", The Stanford Encyclopedia of Philosophy (Fall 2012 Edition), Edward N. Zalta (ed.), retrieved from <http://plato.stanford.edu/archives/fall2012/entries/ weber/ >.

Koopman, C. 2010. "Revising Foucault: The history and critique of modernity." Philosophy \& Social Criticism. 36, 545-565.

Korab-Karpowicz, W. J. 2001. "Martin Heidegger (18891976)," Internet Encyclopedia of Philosophy, October, 23.

Larraín, Jorge. 2000. Identity and Modernity in Latin America. Cambridge: Polity Press.

Lee, Raymond L. M. 2005. "Bauman, Liquid Moderity and Dilemas of Development," Thesis Eleven (83): 61-77 
Lukács, George. 1923. History and Class Consciousness, translation and published by Merlin Press, 1967.

Lukes, Steven. 1973. Emile Durkheim His Life and work, Penguin Books.

Mack, Michael. 2010. Spinoza and the Specters of Modernity: The Hidden Enlightenment of Diversity from Spinoza to Freud, Continuum International Publishing Group.

Marcuse, Herbert. 1964. One-Dimensional Man: Studies in the Ideology of Advanced Industrial Society. Beacon Press.

Marx, Karl and Engels, Fredrick. 1848. The Communist Manifesto, in The Revolutions of 1848: Political Writings (Volume 1), D. Fernbach (ed.), New York: Penguin Classics, 1974.

Mayhew, Leon. 1984. "In Defense of Modernity: Talcott Parsons and the Utilitarian Tradition," American Journal of Sociology, 89(6):1273-1305.

McDonald, William. 2012. "Søren Kierkegaard," Stanford Encyclopedia of Philosophy, First published Dec 3, 1996.

Peters, M., \& Burbules, N. 2004. Poststructuralism and Educational Research. Maryland: Rowan \& Littlefield Publishers.

Redding, Paul. 2010. "Georg Wilhelm Friedrich Hegel," Stanford Encyclopedia of Philosophy.

Ritzer, George and Goodman,Douglas J. 2003. Sociological Theory, $6^{\text {th }}$ edt. McGraw-Hill.

Rohlf, Michael (2010). "Immanuel Kant," Stanford Encyclopedia of Philosophy, May 20.

Rosenau, Pauline Marie. 1992. Post-modernism and the Social Sciences: Insights, Inroads, and Intrusions. Princeton, N.J.: Princeton University Press.

Russell, Bertrand. 1945. The History of Western Philosophy. George Allen \& Unwin Ltd, London.
Seidman, Steven. 1985. "Modernity and the Problem of Meaning: The Durkheimian Tradition," Sociological Analysis, 46(2): 109130.

Sorell, Tom. 1993. The Rise of Modern Philosophy: The Tension between the New and Traditional Philosophies from Machiavelli to Leibniz. Edt. Oxford: Oxford University Press.

Stewart, Matthew. 2006. The Courtier and the Heretic: Leibniz, Spinoza, and the Fate of God in the Modern World, New York: W.W. Norton \& Company, 2006.

Strauss, Leo. 1958. Thoughts on Machiavelli. Chicago: University of Chicago Press.

-------. 1987. "Niccolo Machiavelli". In History of Political Philosophy, third edition, edited by Leo Strauss and Joseph Cropsey, 296-317. Chicago: University of Chicago Press.

Tate, J. W. 1997. Kant, Habermas, and the 'philosophical legitimation' of modernity. Journal of European Studies.

Thornton, Stephen P. 2013. "Karl Popper". Stanford Encyclopedia of Philosophy, First published Thu Nov 13, 1997.

--------. 2010. "Sigmund Freud". Internet Encyclopedia of Philosophy. originally publishes April 162001.

Turner, J. H. 2003. "The Structure of Sociological Theory." Wadsworth Thomson Learning Press.

Weber, Max. 1904-5. The Protestant Ethic and the Spirit of Capitalism. Baehr \& Wells Press. 